\title{
Historie celiakie
}

\author{
Jan Bureš \\ II. interní gastroenterologická klinika LF UK a FN Hradec Králové
}

\section{Souhrn}

Střevní onemocnění se závažnou malabsoprcí připomínající celiakii bylo popsáno již v 15. století před naším letopočtem v Indii. Tento přehledný referát nabízí stručnou historii celiakie od Aretaea z Kapadocie (1. století našeho letopočtu) až po Willema Karla Dickeho (polovina 20. století našeho letopočtu).

Klíčová slova: celiakie - Dicke - Gee - Herter - historie - sprue

\section{History of celiac disease}

\section{Summary}

Intestinal disease with prominent malabsorption resembling celiac disease was already described in India in the 15th century B.C. This review provides a brief history of celiac disease from Aretaeus of Cappadocia (1st century A.D.) to Willem Karel Dicke (mid 20th century).

Key words: celiac disease - Dicke - Gee - Herter - history - sprue

Celiakie je chronická multiorgánová autoimunitní choroba u geneticky predisponovaných osob, dětí i dospělých. Onemocnění je vyvoláno potravou osahující gluten (lepek) [1].

Střevní onemocnění s malabsorpcí bylo popsáno již v 15. století před naším letopočtem v Indii [3]. Název celiakie pochází z řeckých slov koiliakós (коı $ı$ ıкóc břišní) nebo koilia (koı ıı - břicho). Onemocnění bylo známo také v antice, popsal ho Aretaeus z Kapadocie (asi 85-138 n.l.). Aretaeus byl řecký lékař, který studoval v Alexandrii a v Římě a poté působil v římské provincii Kapadocie (dnešní střední Turecko). Popsal chronické střevní onemocnění s poruchou „pepsis“ (trávení) a „anadosis“ (vstřebávání). Příčinu viděl v ochlazení „přirozeného horka“ žaludku, nezbytného pro správné trávení a vstřebávání, a následně v odchodu nestrávené potravy stolicí. Pacienti byli velmi zesláblí, protože „jejich těla byla hladová“ [6]. Aretaeus kromě celiakie popsal řadu dalších onemocnění (bronchiální astma, plicní tuberkulóza, difterická angina, lepra, epilepsie, tetanus, hysterie, manio-melanchonie aj). Sepsal 4 svazky o příčinách a klinických příznacích (De Causis et Signis Morborum Acutorum et Diuturnorum) a 4 svazky o léčbě akutních a chronických chorob (De Curatione Morborum Acutorum et Diuturnorum). V ionské řečtině sepsané dílo bylo až do 16 . století zapomenuto. $V$ roce 1552 bylo celé dílo přeloženo do latiny (v Benátkách) a v roce 1554 bylo znovu uveřejněno v řečtině (v Paříži) [6].

Aragonskýlékař Gerónimo Soriano v roce 1690 v knize o dětských chorobách popsal onemocnění odpovídající celiakii a její odlišení od jiných chronických prů- jmových nemocí. Skotský lékař Matthew Baillie, který zřejmě neznal Aretaeovo dílo, popsal v roce 1793 chronické průjmové onemocnění dospělých, charakterizované malnutricí a vzedmutým břichem s plynem distendovanými střevními kličkami. Na základě svých pozorování navrhnul léčebnou dietu s rýží (some patients have appeared to derive considerable advantage from living almost entirely upon rice) [6].

Slovo „sprue“ je poangličtěný výraz holandského „sprouw" (afta), od roku 1669 používaný pro průjmovité onemocnění s aftózními vředy $v$ ústech (aphthae orientales) u dělníků ve Východní Indii, tedy pro onemocnění dnes označované jako tropická sprue [3]. Termín „tropická sprue“ však zavedl až v době svého působení v Číně (v roce 1880) Sir Patrick Manson, skotský lékař, zakladatel tropické medicíny [6].

Prvním autorem novodobého moderního popisu celiakie byl anglický pediatr Samuel Gee. Profesor Gee se zajímal o dějiny medicíny, byl schopen číst řecké texty a Aretaeovo dílo dobře znal. V roce 1888 podal přesný popis celiakie (celiac affection) jako chronické průjmovité onemocnění s indigescí a steatoreou. Chorobu dětí a onemocnění dospělých (často se vracejících z Indie; zřejmě s tropickou sprue) považoval za jednu nemoc. Byl přesvědčen, že léčba musí být dietou [7]. $V$ roce 1908 popsal americký lékař Christian Herter chronické průjmovité onemocnění, které označil jako tzv. intestinální infantilizmus [10]. Domníval se, že příčina onemocnění je infekční (abnormální perzistence bifidobakterií). Celiakie byla po těchto dvou vědcích označována také jako syndrom Gee-Herter [6]. 
Průkopníky speciálních diet byli americký lékař Sidney Haas (banánová dieta; 1924) [8,9] a švýcarský pediatr Guido Fanconi (ovocné džusy a syrová zelenina; 1928) [5]. Autorem koncepce bezlepkové diety je holandský lékař Willem Dicke. $V$ roce 1936 ho matka dítěte s celiakií upozornila, že kožní projevy (Duhringovy choroby) se výrazně zlepšily po vyřazení chleba z jídelníčku. Propracovaný koncept bezlepkové diety Dicke uveřejnil $v$ roce 1941 [4]. V době tzv. zimního hladomoru v severozápadních provinciích Nizozemska (listopad roku 1944 až květen roku 1945) při totálním nedostatku mouky došlo ke zlepšení projevů celiakie, po leteckých spojeneckých dodávkách mouky do postižených oblastí se pacienti s celiakií rychle zhoršili. Ani tento praktický důkaz zpočátku nestačil. V roce 1947 Dicke přednesl svůj koncept bezlepkové diety na mezinárodním pediatrickém kongresu v New Yorku, nebyl však brán vážně, koncept bezlepkové diety byl odmítnut. Teprve $v 2$. polovině 50. let minulého století se bezlepková dieta stala základem terapie celiakie. $V$ roce 1962 byl prof. Dicke navržen na Nobelovu cenu, zemřel však, aniž se jí dočkal (Nobelova cena se in memoriam neuděluje) [11].

V poslední dekádě došlo $\mathrm{k}$ velkému nárůstu poznatků, medicína dnes lépe rozumí patogenezi, objevila se řada nových léčebných možností. Stručného průvodce historií celiakie je možno zakončit konstatováním, že v současné době je zřejmé, že celiakie není jedna choroba, ale skupina nejméně 3 príbuzných onemocnění [2].

Práce vznikla v rámci projektu PROGRES Q40-15 (Univerzita Karlova), dále podpořeno $M Z C K R-R V O$ (FNHK, 00179906).

\section{Literatura}

1. Bai JC, Ciacci C, Corazza GR et al. World Gastroenterology Organisation Global Guidelines: Celiac disease. Milwaukee: World Gastro- enterology Organisation. 2016. Dostupné z WWW: <http://www.worIdgastroenterology.org/guidelines/global-guidelines/celiac-disease/ celiac-disease-english>.

2. Bureš J. Celiakie a další s glutenem asociované choroby. In: Rokyta $\mathrm{R}$, Höschl C (eds). Moderní medicína - prevence nebo léčba? Axonite CZ: Praha 2017: 12-39. ISBN 978-80-88046-14-1.

3. Cluysenaer OJ, van Tongeren JH. Malabsorption in Coeliac Sprue. Springer Science \& Business Media: Dordrecht 2012.

4. Dicke WK. Eenvoudig dieet bij het syndroom van Gee-Herter [Jednoduchá dietní léčba syndromu Gee-Herter]. Ned Tijdschr Geneeskd 1941; 85: 1715-1721.

5. Fanconi G, Uehlinger E, Knauer C. Das coeliakie-syndrom bei angeborener zystscher pankreasfbromatose und bronchiektasien. Wien Med Wchnschr 1936; 86: 753-756.

6. García Nieto VM. A History of Celiac Disease. In: Rodrigo L, Peńa AS (eds) Celiac Disease and Non-Celiac Gluten Sensitivity. Omnia Science: Barcelona 2014: 45-59. ISBN 978-84-942118-2-9. Dostupné z DOI: <http://dx.doi.org/10.3926/oms.223>.

7. Gee S. On the coeliac affection. St. Bartholomew's Hospital Reports $1888 ; 24: 17-20$.

8. Haas SV. Celiac disease. Its specific treatment and cure without nutritional relapse. JAMA 1932; 99(6): 448-452. Dostupné z DOI: <http://dx.doi.org/10.1001/jama.1932.02740580016004>.

9. Haas SV. The value of banane treatment in celiac disease. Am J Dis Child 1924; 28(4): 421-437. Dostupné z DOI: <http://dx.doi.org/10.1001/ archpedi.1924.04120220017004>.

10. Herter CA. On infantilism from chronic intestinal infection, characterized by the over growth and persistence of flora of the nursling period. A study of the clinical course, bacteriology, chemistry and therapeutics of arrested development in infancy. The Macmillan Company: New York 1908.

11. van Berge-Henegouwen GP, Mulder CJ. Pioneer in the gluten free diet: Willem-Karel Dicke 1905-1962, over 50 years of gluten free diet. Gut 1993; 34(11): 1473-1475.

\section{prof. MUDr. Jan Bureš, CSc., FCMA $\checkmark$ bures@Ifhk.cuni.cz}

II. interní gastroenterologická klinika LF UK a FN Hradec Králové

www.Ifhk.cuni.cz

Doručeno do redakce: 6. 11. 2017 